\title{
Review: A Postcolonial-feminist Interpretation of Marlene Nourbese Philip's Poetry
}

\author{
Yuan Shen \\ University of Jinan \\ Jinan, China 250022
}

\begin{abstract}
Wu Li's A Postcolonial-feminist Interpretation of Marlene Nourbese Philip's Poetry, the first monograph on Philip's poetry in China, is an organic combination of postcolonial interpretation and gender study of the all the 5 collections of Philip's poems originally published between 1980 and 2008. With the help of such subtexts as Philip's website, journal entries, interviews, reviews as well as Philip's personal emails to $\mathrm{Wu}$, this 8-chapter monograph makes multidimensional analyses of Philip's thought-provoking themes of language, culture, identity, exile, history, racism and sexism, her original language view and poetic theory, her unconventional postmodern techniques, experimental poetic devices, anti-writing strategies as well as her female discourse, narrative pattern and body writing skills. Through diachronic analyses of the interaction between Philip's aesthetic texture and identity politics, and synchronic comparison of Philip's poetry with those of other diasporic writers, A Postcolonialfeminist Interpretation successfully penetrates into the historical profundity and cultural connotation of Philip's poetry, illustrates the postcoloniality and Caribbeaness shared by Philip and her contemporary diasporic Caribbean writers, elucidates her explicit or implicit authorial intentions, reveals her hidden or half-hidden composing motivations, and exalts her deep understanding of humanity and multidimensional perception of the multicultural world.
\end{abstract}

Keywords—Marlene Nourbese Philip; postcolonial; feminist

\section{INTRODUCTION}

Marlene Nourbese Philip (1947- ), credited as M NourbeSe Philip, is a distinguished poet, essayist, novelist, playwright, short story writer, and "one of the important pioneers of African-Caribbean-Canadian literature" (Savory, 297). Her thought-provoking works on a large variety of themes, namely cultural displacement, identity, feminism, racism, exile, existentialism, homecoming, etc., not only earn her numerous rewards and grants in Canada, Caribbean countries and Latin America, such as runner-up for the Canadian Library Association Book of the Year for Children Award, winner of the Canadian Children's Book Centre's Choice Award, the Max and Greta Abel Memorial Award for Multicultural Literature, Toronto Arts Award in writing and publishing, the prestigious Casa de las Américas Prize for poetry, Guggenheim Fellowship in poetry, McDowell Fellowship, Chalmers Fellowship in Poetry, Rockefeller Foundation residency, but also win many ardent readers and admirers in the world. $\mathrm{Wu} \mathrm{Li}$, an associate professor of English at the University of Jinan in East China, is one of them.

The experimental anti-traditional expression, unique aesthetic features and rich historical and cultural connotations of Philip's poetry have attracted much attention of critics, scholars and researchers in Great Britain, the United States, Australia and China. However, although hundreds of papers on Philip's works have been distributed in academic journals around the world, so far, few in-depth systematic monographs on Philip's works have been published. Wu Li's monograph A Postcolonial-feminist Interpretation of Marlene Nourbese Philip's Poetry (published by Shandong University Press in August 2017, hereafter shortened as A Postcolonial-feminist Interpretation), is the first monograph on Marlene Nourbese Philip's poetry in China, and successfully fills the gap in the study of Philip's poetry.

\section{THE SCOPE OF A POSTCOLONIAL-FEMINIST INTERPRETATION}

The reconstruction of postcolonial cultural identity and the construction of female identity are two important dimensions of Philip's poetry, both of which belong to the category of identity political writing. So, Wu focuses on these two dimensions, i.e. the postcolonial traits and gender characteristics of Philip's poetry, and attempts to make $A$ Postcolonial-feminist Interpretation an organic combination of postcolonial interpretation and gender studies, which targets at a thorough and deep interpretation of all the 5 collections of Philip's poems originally published between 1980 and 2008, namely Thorns (1980), Salmon Courage (1983), She Tries Her Tongue; Her Silence Softly Breaks (1989), Looking for Livingstone---an Odyssey of Silence (1991) and Zong! (2008)

At the same time, Wu attempts to interpret Philip's poetry with the tradition and genealogy of African and Caribbean cultures and literatures as its historical and cultural contexts, which successfully helps to expound Philip's inheritance of the African and Caribbean cultural and literary legacy. By comparing and contrasting Philip's works with other writers like Alice Walker, Toni Morrison, Derek Walcott, V. S. Naipaul, Edwidge Danticat, Caryl Phillips, Samuel Selvon, George Campbell, Frank Collymore, Clara Mauder Garrett, George Lamming and so on, A Postcolonial-feminist Interpretation also shows the 
common Africanness or Caribbeaness in the works by Philip and other writers of African or Caribbean origin, and the shared postcolonial qualities of Philip and other diasporic Caribbean writers, who have the similar diasporic background and face the similar cultural hybridization.

\section{The STRUCTURE OF A POSTCOLONIAL-FEMINIST INTERPRETATION}

A Postcolonial-feminist Interpretation is composed of 8 parts, and each part is as follows:

Part I, "Exile and Identification", studies such typical topics in Philip's poetry as cultural displacement, identity anxiety, hometown writing, home-returning, i-mage, cultural colonization, and shows the Afro-Caribbean people's anguish in being culturally lost and their painstaking struggle for survival and perseverant effort in reconstruction of cultural identity.

Part II, "Linguistic View and Strategies", explores Philip's language view, linguistic style and poetic devices in 6 chapters, namely, "The Binary of Mother/ Father Tongue and the Anguish of Aphasia", "Refactoring Language: Creole and the Caribbean Demotic of English", "Bilingual and Multi-lingual Writing", "Kinopoesis", "Carnivalesque Languages and Texts", "The Relationship Between Language and Silence". These chapters analyze Philip's efforts to get rid of the pain of aphasia, establish the cultural status of her native language and create "the continuum of expression from standard to Caribbean English"(Philip, 1997: 51) which is "both a creolized dynamic language following the poetics of moving and kinetics, which she terms 'kinopoesis' and which is part of the African aesthetic, and a carnivalesque discourse breaking through the laws and established patterns of standard English censored by grammar and semantics" (Wu \& Zhao, 2015: 74), to get "her revenge on 'this/ fuck-mother mother fuckin language' of the colonizer" (Philip, 2008: 205), to subvert the language hegemony of imperialism through the carnival of language and text which focuses on the kinetic quality of language, and to achieve greater freedom of expression through her "Babel-sque languages" (Williams, 786) as well as multiple and many-voiced fugal form.

Part III, "Historical Reverse-writing", is Wu's new historicist critical practice, which contrasts the traditional image of Livingston, the discoverer of Africa in the western historical writing, with the totally different image of Livingstone in Looking for Livingstone---an Odyssey of Silence, the destroyer of Africa, so as to reveal Philip's strong sense of historical responsibility, and to interpret her resistance against western history and her deconstruction of the so-called authoritative archives as well as her aspiration to rewrite the African history.

Part IV, "Deconstruction and Reconstruction: Antiwriting Strategies", analyzes Philip's postcolonial antiwriting strategies in four chapters, namely, "Collage and Blend", "Polyphony and Fugue", "Fragmentation", "Sound Poetics". Through close reading of Philip's intricate, sometimes even difficult, experimental poems, $\mathrm{Wu}$ successfully interprets the rich historical and political meaning of Philip's anti-traditional postmodern techniques, and her ambition to "dispel the authority and oneness of the original writing (the empire writing), to form a kind of polyphonic historical writing, and to reconstruct a new history discourse in the adversarial relationship" (Ren, Xii) for the sake of "challenging the conventions of classical western poetic devices" (Wu \& Zhao, 2015: 74) and genre writing patterns, reconstructing her own way of expression, and obtaining her "greater freedom within limitation".

Part V, “Other's Other: The Identity Crisis and Dilemma of Women", by discussing 4 types of women images in Philip's poems, namely, silenced females, confused girls, miserable women and helpless mothers, delineates the plight of silent African-Caribbean women, as well as their physical and mental anguish, identity anxiety and existential crisis caused by multiple oppression, such as racial discrimination, class discrimination and gender discrimination.

Part VI, "Sexual Politics: Sexual Wars and Female Breakout", starts with a comparison between Philip's poems with Doris Lessing's works to discuss how should women win the "sempiternal sexual wars" as well as the "freedom guerilla-garbed/ in relationships struggles", expand their "existential boundaries" (Philip, 1980: 25), and establish their independent personality and identity. It also explores how Philip establishes a women-only society through cultural patricide, and creates her female lineage and maternal mythology. From the perspective of feminism, Wu eulogizes Philip's portrayal of the respectable and courageous African-Caribbean women, their high morale in the protracted sexual struggles to realize their political demands of sexual equality, to demolish the patriarchal yoke and build their own survival approaches, interpretation system and corresponding mode.

Part VII, "Female Discourse and Narrative", consists of four chapters. Chapter 1, on the basis of Hélène Cixous's theory of écriture feminie, explores such features of female discourse as repeated central themes and images, metaphorical codes and non-linear narration. Chapter 2 illustrates Luce Irigaray's theory of parler femme and Julia Kristeva's semiotics theory through analyses of the gender discourse characteristics of Philip's poetry from three aspects: the decentralization and non-coherence features of grammar and syntax, the irrational features, the improvisation and repetition of language, etc. Chapter 3 and 4 , on the basis of feminist narrative theory, explore Philip's female perspective of poetry and narrative mode, interpret the rhetoric features of the female narrative subject and perspectives embodied in the collective narrative voice, and analyze the artistic effect, aesthetic characteristics, and the rich philosophical, historical and cultural connotations conveyed through women writers' nonlinear time system and narrative mode.

Part VIII, "Body Writing”, analyzes Philip's unique body writing theories and literary practice to display women's "fantastic tumult of drives" (Cixous, 876), inexhaustible imaginary and beauty, and incredible creative power in 2 chapters. Chapter 1 discusses how Philip 
practices Cixous's advocacy in The Laugh of the Medusa that "women must write through their bodies, they must invent the impregnable language that will wreck partitions, classes, and the rhetorics, regulations and codes, they must submerge, cut through, get beyond the ultimate reversediscourse" (886). Philip explains the importance of the African body and her fascination with body writing in $A$ Genealogy of Resistance and Other Essays as follows:

The African body. At cross purposes with the African body---

the African body: spirit

the African body: intelligence

the African body: memory

the African body: creativity

: its resources

Time and again these resources impelling her to flee, run from, subvert, the institution of slavery. (1997: 91)

So, in Chapter 2, Wu goes beyond Cixous's idea of femininity of women's body writing, extends her interpretation of Philip's body writing into Foucault's new historical criticism, his genealogy of the body and the new horizon of political rhetorics, and analyzes how Philip manages to materialize her ideological intention and political appeal for constructing history through desexualized body writing, with the African-Caribbean body experience both as the medium for writing history and an indispensable link in the genealogy of resistance, subversion and deconstruction.

By summarizing the main content of A Postcolonialfeminist Interpretation, we have very good reasons to say that Wu's interpretation of Philip's poetry successfully breaks through the thinking mode of taking aesthetics and politics as binary oppositions. By focusing on the interaction between Philip's aesthetic texture and identity politics, $\mathrm{Wu}$ explores the organic unification of poetic artifices and culture strategies, Philip's poetic originality and female consciousness, and makes every effort to show both the ethnic characteristics and gender characteristics of Philip's poetry, her deep understanding of humanity and her multidimensional perception of the multicultural world.

\section{THE ORIGINALITY OF A POSTCOLONIAL-FEMINIST INTERPRETATION}

Philip, as a diasporic African-Caribbean female poet who faces the blend, hybridity and collision of different cultures as well as the double marginalization as "other's other" in ethnic and gender identities, is very much concerned with the diasporic individuals' construction of ethnic and national identity and their cultural orientation. Based on this understanding, $\mathrm{Wu}$ focuses on the interdependent linkage of cultural and gender identification with Philip's literary narrative, trying to carry on a theoretical expression of its internal structure and principle, to highlight the complementary relation between her aesthetic characteristics and her original construction methods of cultural and gender identity. In this sense $A$ Postcolonial-feminist Interpretation is an organically wellbalanced exploration of Philip's poetic art and identity politics.

Moreover, the postcolonial traits and gender characteristics of Philip's poetry find their way to Wu's monograph "both diachronically and synchronically" (Wu, 2017: 211). In a synchronic sense, Wu attaches due importance to the postcolonial-feminist texture of Philip's poetry in terms of themes, subjects, stylistic features, archetypal images, typography, grammatical variation, narrative strategies and gender discourse, etc., to provide a polyphonic view on language, culture, gender and ethnic identity through text analysis. In a diachronic sense, Wu accentuates an African-Caribbean cultural and literary genealogy to penetrate into the historical profundity of Philip's poetry, to illustrate the postcoloniality and Caribbeaness shared by Philip and other diasporic Caribbean writers, and to elucidate Philip's unique preservation and representation of Caribbean cultural and literary traditions.

Another originality of A Postcolonial-feminist Interpretation lies in the perfect combination of novel topic selection, complex research objects and unique perspectives and methods. Philip is greatly influenced by African, Caribbean, British, Canadian, and American cultural heritages, which made her poems culturally colorful. Facing such a complex and unique research object, no single discipline study method nor commentary approach is capable of "grasping the ungraspable in M. NourbeSe Philip's poetry" (Moïse, 23) or deeply explaining their uniqueness and richness. Therefore, A Postcolonial-feminist Interpretation puts Philip's poetry under the vision of multiculture study and adopts the method of interdisciplinary infiltration to conduct a multidimensional research, which combines macro description of historical and cultural background with micro analyses of themes, imagery and cultural metaphors, deep inquiry of latest theoretical problems with detailed text reading, diachronic inspection with the synchronic exploration, rational analyses with passionate empathy .

The unavailability of Philip's works and the scarcity of Philip's readers and translators in China make it rather difficult for $\mathrm{Wu}$ to conduct thorough research on Marlene Nourbese Philip. What's more, both Philip's original experiment on language and her postmodern artifices of form render it even more challenging to interpret her poems adequately. To solve the first problem, Wu not only manages to contact Philip herself through the email address in her website, who kindly posted $\mathrm{Wu}$ all her works available and relevant materials, including the PDF versions of out-of-print early collections and the cassettes of Harriet's Daughter, but also painstakingly translates many of Philip's poems and introduces them to hundreds of university students and scholars through lectures, seminars, literary saloons, academic conferences and international conventions. To solve the second problem, $\mathrm{Wu}$ has not only managed to keep contact with Philip herself, believing that the author's own explanation of various questions 
concerning her poetry is the most convincing interpretation, but also has been to universities in England and America as a visiting scholar and has collected hundreds of relevant essays and monographs in several universities' libraries for reference. Finally, with the help of such personal subtexts as Philip's website, journal entries, interviews, reviews as well as Philip's personal emails to $\mathrm{Wu}$, Wu's monograph successfully reveals Philip's hidden or half-hidden composing motivations and authorial intentions, and explains the original techniques and experimental devices that Philip applies "to break up, to destroy; and to foresee the unforeseeable, to project" as Cixous wished (875), and at the same time, to "display historical analysis, anger, sardonic burnout, fantasy, and deconstructive word play to make a variety of points about exile, loss of language and culture, and the search for cultural roots and contemporary meaning" (Morrell, 156).

\section{CONCLUSION}

In closing, Wu's A Postcolonial-feminist Interpretation of Marlene Nourbese Philip's Poetry, the first monograph on Philip's poetry in China, is highly recommended for its capacity for arousing more Chinese scholars' further interest in Marlene Nourbese Philip and other diasporic Caribbean writers, and its capability of inspiring further meditation on the establishment of national cultural identity in the context of globalization.

\section{REFERENCES}

[1] Cixous, Hélène. "The Laugh of the Medusa," Trans. Keith Cohen and Paula Cohen. Signs, Summer (1976): 875-893.

[2] Moïse, Myriam. "Grasping the Ungraspable in M. NourbeSe Philip's Poetry," Commonwealth Essays and Studies, 33.1 (2010): 23-33.

[3] Morrell, Carol. "Humanities," Letters in Canada, 1(2012):154-156.

[4] Philip, Marlene Nourbese. Thorns. Toronto: Williams-Wallace International Inc., 1980.

[5] Philip, Marlene NourbeSe. A Genealogy of Resistance and Other Essays. Toronto: The Mercury Press, 1997.

[6] Philip, Marlene NourbeSe. Zong!. Middletown: Wesleyan University Press, 2008.

[7] Ren Yiming. Post-colonialism: Critical Theory and Literature. Beijing: Foreign Language Teaching and Research Press, 2008.

[8] Savory, Elaine. "Marlene Nourbese Philip," Dictionary of Literary Biography, Volume 157: Twentieth-Century Caribbean and Black African Writers, Third Series. Eds. Bernth Lindorfs and Reinhard Sander. Detroit: Gale Research Inc., 1996: 296-306.

[9] Williams, Tyrone. "Marlene Nourbese-Philip's Zong!" African American Review, 4 (2009): 785-787.

[10] Wu Li \& Zhao Jing. "Bilingualism, Creolization and Kinopoesis: On M. NourbeSe Philip's View of Language and Poetic Strategies," Shandong Foreign Language Teaching, 2 (2015): 74-82.

[11] Wu Li. A Postcolonial-feminist Interpretation of Marlene Nourbese Philip's Poetry. Jinan: Shandong University Press, 2017. 